\title{
A Cytomegalovirus Infection Case Mimicking Total Parenteral Nutrition Associated Cholestasis
}

\section{Total Parenteral Nütrisyonla Illişkili Kolestaza Benzeyen Bir Sitomegalovirus Enfeksiyonu Vakası}

Musa Silahli,

Zeynel Gokmen,

Baskent University Faculty of Medicine,

Konya Practice and Research Hospital. Child Health and Diseases, USA, Neonatology

Department

Geliş Tarihi/Received: 9 April 2017

Kabul Tarihi/Accepted: 23 November 2017

Address correspondence to: Musa Silahli, Baskent University Faculty of Medicine,

Konya Practice and Research Hospital. Child Health and Diseases, USA, Neonatology Department, Konya

e-mail: msilahli@gmail.com

ORCID

Musa Silahli

https://orcid.org/0000-0003-0944-7178

\begin{abstract}
Öz
Sitomegalovirus (CMV) erken süt çocukluğu döneminde transplasental geçiş gösteren en sık karşılaşılan virüslerden biridir. Ve non-herediter sensörinöral işitme kaybı nedenleri arasında en sık karşılaşılan enfeksiyöz sebeptir. Burada 29 haftalık aşırı düşük doğum ağırıkı (ADDA) $460 \mathrm{gr}$ TPN ilişkili kolestaza benzeyen CMV enfeksiyonu geçiren olguyu sunmaktayız. Uzun süre TPN ile beslenen ADDA prematüre bebekte genellikle kolestaz ilk önce TPN ile ilişkili olduğu düşünülür. Direkt hiperbiluribinemi ve kolestaz yeni doğan döneminde sık karşılaşılan problemlerden biridir. Özellikle bu durumlar genellikle sepsis, TPN alımı, doğuştan metabolik hastalıklar ve diğer sebeplerle ilişkili olduğu düşünülür. Özellikle ADDA infantlarda ve uzun süre TPN ile beslenen bebeklerde CMV enfeksiyonları aklımızın bir köşesinde bulunmalıdır.
\end{abstract}

Anahtar Kelimeler: Kolestaz,CMV enfeksiyonları,TPN

\section{Abstract}

A case of cytomegalovirus infection mimicking total parenteral nutrition associated. Congenital cytomegalovirus (CMV) infection is the most common infection that passes trough transplacentally in the early infancy period and is the most common infectious cause of the nonhereditary sensorineural hearing loss. We know that most of these cases were asymptomatic in the neonatal period. Especially among the extremely low birth weight infants, CMV prevalence is not known. We present a 29 weeks old $460 \mathrm{gr}$ extremely low birth weight (ELBW) infant with congenital CMV infection mimicking total parenteral nutrition (TPN) associated cholestasis. Usually, when we see the cholestasis in the extremely low birth weight infant feeding with long time TPN, we think that it is associated with TPN. Direct hyperbilirubinemia and cholestasis are the common situations in the newborn period. Especially this is considered to be associated with sepsis, TPN, inborn errors of metabolism and other causes. CMV-associated cholestasis should be kept in mind, especially in cases of premature infants with cholestasis and extremely low birth weight infants have been fed for a long time TPN.

Keywords: Cholestasis, CMV infections, TPN

\section{INTODUCTION}

Congenital CMV infection may cause a lot of clinical signs like intrauterine death, neonatal death, growth restriction, thrombocytopenia, neurological abnormalities, developmental delay, hepatitis, retinitis, hearing loss etc (1). During pregnancy CMV infection can be the form of primary, re activation or reinfection. Virus can be transmitted to anyone by saliva, urine, sexual contact, breastfeeding, solid organ transplantation and vertically. Non primary infections are more common than primary infections and seem to be associated with more neurological disabilities (2). Both primary and non- primary infections may be usually asymptomatically in the healthy individuals or pregnant women. Fetus and immuncomprimised individuals are severely affected by CMV infections. Prevalence of congenital CMV infection is estimated

Cite this article as: Silahli M, Gokmen Z. A cytomegalovirus infection case mimicking total parenteral nutrition associated cholestasis. Selcuk Med J 2019;35(2): 118-120 to range between $0,2 \%$ and $2 \%$ ( 3 ). In country that higher maternal CMV seroprevelance, it is more than this range (4). CMV is most commonly defined virus in the preterm baby less than 32 weeks gestational age and is mainly acquired from breast milk with CMV seropositive mother (5). Postnatal acquired CMV infection is usually asymptomatic. Long term sequelaes of postnatal CMVinfection have less common neurologic impairment according to the congenital CMV. CMV infection is diagnosed by viral culture or real time polymerase chain reaction (rtPCR) of urine, blood or saliva. The treatment of congenital CMV infections is controversial. Although there is no clinical study with large series about congenital CMV hepatitis, it can be lethally. So we present a ELBW infant that has CMV hepatitis for emphasize the difficulties of diagnosis at the congenital CMV 
infection between perinatally acquired CMV infection.

\section{CASE}

A preterm, extremely low birth weight, growth restricted baby who birth weight was 460 gram (below 10th p), delivered by emergency caesarian section for fetal distress and prolonged rupture of fetal membranes at 29 weeks gestational age. She had no spontaneous breathing at birth and APGAR scores were 2 in one minute and 3 in five minutes. Length, weight and head circumphrence were 27 $\mathrm{cm}, 460 \mathrm{gr}$ and $22,5 \mathrm{~cm}$, respectively. All of them were below 10th percentile. After the delivery room stabilization, she was admitted to the neonatal intensive care unit. After the surfactant administration and catheterization of the umbilical artery and vein, fluid resuscitation was started. At the postnatal first day minimal enteral nutrition was started by breast milk. But because of abdominal distension and asymmetric IUGR was not achieved nutrition more than minimal enteral nutrition for first 21 days. Total parenteral nutrition (TPN) was continued until day of 39. Until the end of the hospital discharge, she had no proven bacterial sepsis. Several types of antibiotics were used because of suspected sepsis. Erythrocyte suspension was given 3 times. These blood products were irradiated and passed through leukocyte filter. Liver enzymes were increased 3-fold. Initially it was thought to be associated with TPN cholestasis. When cholestasis was apparently seen, tests were planned for etiology of cholestasis. At the follow- up maximum values of alanine transaminase (ALT), aspartate aminotransferase (AST), Gammaglutamyl transferase (GGT), total bilirubin, direct bilirubin were $327 \mathrm{U} / \mathrm{L}, 309 \mathrm{U} / \mathrm{L}, 288 \mathrm{U} / \mathrm{L}, 11.42 \mathrm{mg} /$ $\mathrm{dl}, 7.98 \mathrm{mg} / \mathrm{dl}$ respectively. Abdominal USG, reducing substances in urine, alpha 1 antitrypsin level, tandem mass spectrometry and urine organic acid profile were normal. Urine culture and blood culture were negative. Thyroid function tests and cystic fibrosis striple mutation analyze were normal. CMV Ig M and CMV total antibodies were positive and at the postnatal 84th day CMV- DNA rtPCR was 55700 copies $/ \mathrm{ml}$ from blood sample. No calcification was observed on the cranial computed tomography. Eye examination was not revealed chorioretinitis. Newborn hearing screening test performed by ABR was normal. In Our patient's value of the avidity is slightly higher in 63th of life. Maternal CMV Ig M antibody was negative. Maternal CMV Ig G and avidity were positive highly at the postnatal 70th day. Because of not enough data about pregnancy, patient's CMV condition was not understood. Is it congenital CMV or postnatal CMV? At the follow-up the values of liver enzymes and bilirubin had begun to fall without any medication. After the 125 days of hospital stay the patient was discharged to come to follow. At the follow-up the patient's value of CMV DNA was negative.

\section{DISCUSSION}

With the advances in technology in NICU, the usage of TPN increased so the survival rate of premature infants increased significantly. Morbidity associated with prematurity increased. Cholestasis and abnormal liver function tests became observed in almost ELBW infants. TPN associated cholestasis has received the most attention due to the liver damage sustained. TPN associated cholestasis became to very important issue in neonatologist.

TPN associated cholestasis is defined that direct bilirubin level of $>2.0 \mathrm{mg} / \mathrm{dl}$ following a prolonged course of TPN (>2 weeks) and other causes, including surgical and metabolic diseases, have been ruled out. If other specific causes of liver injury are excluded, this disorder is termed parenteral nutritionassociated liver disease or parenteral nutritionassociated cholestasis. Research has revealed that in premature infants, particularly those with very low birth weights, the incidence of TPN associated cholestasis is as high as $50 \%$ (6). The cholestasis and liver test abnormalities tend to advance after the parenteral therapy is discontinued, but may continue in some cases. Among infants who developed TPN associated cholestasis in a neonatal intensive care unit, and had conjugated bilirubin $>2 \mathrm{mg} / \mathrm{dL}$ before two months of age, 17 percent died or went on to liver transplantation (8). Among those with a maximum conjugated bilirubin $>10 \mathrm{mg} / \mathrm{dL}, 38$ percent died or went on to liver transplantation.

CMV is a virus seen in worldwide. CMV infections can affect any part of body. The infection is usually asymptomatically in healthy people. Population based studies showed that CMV seroprevalence is varied from $45 \%$ to $77 \%$ in different societies (7). Most newborns with congenital CMV are asymptomatic at birth but as many as 15 percent will develop progressive hearing loss.

There is no wide case series about congenital CMV hepatitis in the literature. One article suggests that congenital CMV hepatitis is a self limited illness, it has favorable outcome and the treatment is not necessary (9). The treatment issue is controversial. 
Some authors advocate treatment by the viral load levels (10).

Our patient had received long term TPN and was ELBW infant. Initially we considered that this was a TPN associated cholestasis as a lot of neonatologists. But the situation became more complex; we started thinking about differential diagnosis of etiology of neonatal cholestasis. Majority of congenital CMV infections is considered asymptomatic, urine rtPCR CMV DNA may be useful first 3 weeks of life particularly ELBW infants. Because these infants cannot achieve full enteral nutrition for a long time. We follow-up clinically the our patient with no treatment. Most of this infants have developed clinical and laboratory findings of cholestasis. The lack of our case was not made liver biopsy because of extremely low birth weight.

Especially neonatal cholestasis was seen most of the ELBW infants. Therefore if the ELBW infant has cholestasis, other causes of neonatal cholestasis must be excluded. CMV infection should be in a particular corner of mind. We suggest that CMV should be investigated for suspicion of the human milk transmission. Particularly ELBW infants should be done urine or blood rt-PCR analyzes for CMV in the first 3 weeks of life.

Conflict of interest: Authors declare that there is no conflict of interest between the authors of the article.

Financial conflict of interest: Authors declare that they did not receive any financial support in this study.

Address correspondence to: Musa Silahli, Hocacihan mah. Palace CD. No:1 Başkent University Konya Practice and Research Hospital. No: 1 Selçuklu / Konya.

E-mail: msilahli@gmail.com

\section{REFERENCES}

1. Dollard SC, Grosse SD, Ross DS. New estimates of the prevalence of neurological and sensory sequelae and mortality associated with congenital cytomegalovirus infection. Rev Med Virol 2007;17:355-63.

2. de Vries JJ, van Zwet EW, Dekker FW, et al. The apparent paradox of maternal seropositivity as a risk factor for congenital cytomegalovirus infection: A population-based prediction model. Rev Med Virol 2013;23:241-9.

3. Kenneson A, Cannon MJ. Review and meta-analysis of the epidemiology of congenital cytomegalovirus (CMV) infection. Rev Med Virol 2007;17:253-76.

4. Zhang XW, Li F, Yu XW, et al. Physical and intellectual development in children with asymptomatic congenital cytomegalovirus infection: A longitudinal cohort study in Qinba mountain area, China. J Clin Virol 2007;40:180-5.

5. Hamprecht K, Maschmann J, Vochem M, et al. Epidemiology of transmission of cytomegalovirus from mother to preterm infant by breastfeeding. Lancet 2001;17:513-8

6. Suchy FJ. Approach to the infant with cholestasis. In: Suchy J, Sokol RJ, Balistreri WF, editors. Liver Disease in Children. 2nd edition. Lippincott, Williams \& Wilkins; Philadelphia, 2001:187-94.

7. KorndewalMJ,MollemaL, Tcherniaeval,etal.Cytomegalovirus infection in the Netherlands: Seroprevalence, risk factors, and implications. J Clin Virol 2015;63:53-8.

8. Willis TC, Carter BA, Rogers SP. High rates of mortality and morbidity occur in infants with parenteral nutrition-associated cholestasis. J Parenter Enteral Nutr 2010;34:32.

9. Hasosah MY, Kutbi SY, Al-Amri AW, et al. Perinatal cytomegalovirus hepatitis in Saudi infants: A case series. Saudi J Gastroenterol 2012;18:208-13.

10. Lanari M, Lazzarotto $T$, Venturi $V$, et al. Neonatal cytomegalovirus blood load and risk of sequelae in symptomatic and asymptomatic congenitally infected newborns. Pediatrics 2006;117:76-83. 